\title{
How Do I Count Thee? Various Angles for Examining the Doubling Times of the Amish ${ }^{1}$
}

\author{
Joseph F. Donnermeyer \\ Emeritus Professor/Academy Professor \\ School of Environment and Natural Resources \\ The Ohio State University \\ donnermeyer.1@gmail.com
}

\begin{abstract}
The focus of this article is the measurement of how rapidly various parts of Amish society grow, including the number of settlements, households, church districts, and ordained men. "Amish society" means those Plain Anabaptist communities that both identify themselves as Amish and forbid car ownership. Doubling time was selected as the statistic to examine this growth. It is a measure of how quickly a population doubles; that is, its exponential growth. Most of the doubling times calculated for this article were within a few years of the doubling time estimate of 20 years for the Amish population in general, based on statistics from the Young Center for Anabaptist and Pietist Studies. The article concludes with a discussion of what these measures of growth mean for the future of Amish society and extrapolations, based on current doubling times, by decade from 2020 to 2050. Recommended is a greater focus among Plain Anabaptist scholars on the population dynamics of the Amish, arguing that demographic dimensions underlie possible changes in the social, cultural, religious, and economic features of the Amish through the remainder of the twenty-first century.
\end{abstract}

Submitted November 3, 2020; accepted December 18, 2020; published March 24, 2021 https://doi.org/10.18061/jpac.v1i2.7990

Keywords: demography, doubling time, constant annual percentage increase, social and cultural change, The Diary, Raber's Almanac

\section{Introduction}

With apologies to the nineteenth-century poet Elizabeth Barrett Browning, whose verse is mimicked in the first half of the title for this article, ${ }^{2}$ there are indeed several different ways to examine the growth of Amish society. That is the objective of this article: to ask the research

\footnotetext{
${ }^{1}$ I gratefully acknowledge the assistance of Edsel Burdge Jr., research associate at the Young Center for Anabaptist and Pietist Studies. His demographic expertise was quite valuable for development of this manuscript. In addition, I acknowledge two primary sources of data used for the calculation of doubling times: the Pathway Heritage Historical Library (Alymer, Ontario) and the Ohio Amish Library (Berlin, Ohio). Finally, I want to recognize the excellent copyediting by Cynthia Nolt on this and all the articles published in $J P A C$.

${ }^{2}$ Elizabeth Barrett Browning was an internationally known nineteenth-century English poet who was also married to a well-regarded poet, Robert Browning. The poem "How Do I Love Thee" is the forty-third sonnet in her famous collection titled Sonnets from the Portuguese (published in 1850). The first line is one familiar to millions of people around the world, even today: "How do I love thee, let me count the ways."
} 
question, how quickly do the Amish double in size across the various terrains of their social organization? Certainly, one of the ways to examine doubling time is to look at the growth of the population, but there are other ways to examine it as well. One is to look at how quickly the number of settlements becomes twice as large. Still another is to see how rapidly the number of Amish households grows. A third is to examine increases in the number of church districts and the number of ordained men over time.

There is a great diversity of Plain Anabaptist communities. The Amish who form the focus of this article prohibit the ownership of motor vehicles and identify as Amish. Within this group alone is a great amount of diversity, but even more variety exists in the full range of Plain Anabaptist communities; however, those known as Beachy Amish, Amish-Mennonites, and horse-and-buggy Mennonites are not the focus of this article.

Population growth in any society, large or small, is a product of two interrelated factors. These are, first, the net natural change in the population; that is, the difference between the number of births and the number of deaths in a given society (Bogue, 1969). In more technologically advanced societies, fertility may be much lower than when these same societies were mostly agrarian, but then again, health and dietary standards reduce death rates and extend life expectancy. The second is the difference between the number of persons who migrate into a society versus the number who migrate out (Bogue, 1969). Some societies today experience high rates of inmigration, while others experience very little. Likewise, out-migration varies from one country to the next. By adding together net natural increase (births minus deaths) and net migration (inmigration minus out-migration), a change in a society's population can be calculated and then a doubling time can be determined.

Yet, doubling time is more than a number that pertains to the study of the relative growth of human populations. Doubling time can be applied in the same way and with the same formulas to a variety of phenomena, such as the time it takes for the bacteria in a test tube filled halfway with bacteria to take over the whole glass container, the growth of cancer cells in the human body, and the speed with which one's savings account deposits at a bank or one's 401K plan grows. Hence, in its essence, doubling time is an increase in something measured over a specific period of time, and then compounded (i.e., multiplied by the product of the previous multiplication) over time periods of the same length until the original number has doubled in size. The number of time periods required for this to happen is the doubling time. So, for example, an average increase of $0.1 \%$ over a specific time period means that it will require about 693.5 of the same time periods for a population to double. On the other extreme, a $40.0 \%$ increase over a given time interval will mean the population doubles in only 2.06 of the same time interval (Allendoerfer \& Oakley, 1955; Bogue, 1969). Of course, both of these examples assume little or no variation in the rate of change across the multiple time periods. 


\section{Research Question}

On the Amish Studies website of the Young Center for Anabaptist and Pietist Studies is an estimate that the Amish population doubles approximately every 20 years (Young Center for Anabaptist and Pietist Studies, 2020a). For a faith group the size of the Amish, this is a phenomenal rate of growth. A small, newly formed church group can certainly grow at a much faster pace, but the Amish are not new and they number between 330,000 and 350,000 individuals. Even though this is a small percentage of the total population of their host countries, namely Canada and the United States (more recently, Argentina and Bolivia, as well), it is nevertheless the case that a doubling time of 20 years is incredibly short for a human population of this size. For example, population growth in Canada was 1.4\% between 2018 and 2019, and in the United States, it was 0.5\% (World Bank, n.d.). These percentage increases represent doubling times of nearly 50 years and 139 years, respectively. Keep in mind, also, that the Amish is a faith group based on voluntary membership through baptism and obedience to a church discipline, or ordnung in the Pennsylvania Dutch language. A low rate of retention among children born into Amish families when they reach the age of decision for baptism would mean a much higher doubling time, and therefore, a slower rate of population increase. Conversely, a high rate of retention likely means a lower doubling time; hence, a higher rate of population increase. In this sense, retention is like a measure of net migration - those who join minus the sum of those who do not join and those who leave the Amish faith sometime after baptism. Although rates vary from settlement to settlement and across the various fellowship groups of Amish, all suggest that, over time, the baptism rate today is generally considered to exceed $80 \%$ and to perhaps be as high as 90\% (Kraybill et al., 2013, pp. 162-163).

In the past, there were a number of demographic studies of the Amish population, including studies from the twentieth century by Smith (1960), Cross (1976), Cross and McKusick (1970), Markle and Pasco (1977), Ericksen, Ericksen, Hostetler, and Huntington (1979), Ericksen, Ericksen, and Hostetler (1980), Meyers (1991; 1994), Wood et al. (1994), and Wasao and Donnermeyer (1996), among others. Nearly all of them comment on the high fertility rates and above average population growth of the Amish. For example, a half century ago Ericksen, Ericksen, Hostetler, and Huntington (1979, p. 255) described Amish fertility as "one of the highest in the developed world." Even though Amish population research and commentary is less frequent in the twenty-first century (so far), scholars such as Greksa (2002, 2004), Greksa and Korbin (2002), and Kraybill et al. (2013) continue to regard the Amish as distinctive from mainstream North America, not only on the basis of their communal and socioreligious dimensions, but also by their fertility rates, family size, and population growth.

The Young Center estimate of the doubling time of the Amish is based on a calculation of the average population size of a church district along with a count of the number of church districts. This is a good way to go about establishing a doubling time estimate because it compares population size differences over time using the same method for calculating population size at specific points in time. 
The research question addressed in this article is the following: Beyond the doubling time based on population increase as found on the Young Center's Amish Studies web page (Young Center for Anabaptist and Pietist Studies, 2020a), to what extent does Amish society grow by other features of its social organization, such as the number of settlements, the number of households, the number of church districts, and the number of ordained men? If estimated from these various angles, would the differences in their doubling times be large, moderate, or small when compared to the 20 -year doubling time of the population as calculated by the Young Center?

\section{Methodology}

In a perfect world, the most direct way to measure the doubling time of the Amish population would be to determine as precisely as possible how many Amish men, women, and children there are, and to calculate a total every year or for some other standard period of time. An average of these periodic changes would provide a solid statistic of Amish population doubling time. This is simply impossible, even though there are dozens of directories published every year listing Amish families. Unfortunately, there is not a single, comprehensive directory published at regularly occurring time periods of all Amish living in the nearly 600 settlements that exist today. For one thing, the directories of different settlements are published in different years and the time period between the publication of directory editions also varies. For example, recent directories for the large Greater Lancaster County settlement were published in 1996, 2002, and 2016, whereas, for the nearly-as-large Greater Holmes County community, directories are now published every five years. In addition, there are no directories for many settlements, especially those of more conservative affiliations and those that are newer.

Because the ideal Amish census is not and will never be possible, various proxies or substitutes for calculating doubling time are necessary. For example, the average number of people within a church district (both adults and children) multiplied by the number of church districts, which is how the Young Center determined the estimated doubling time of 20 years, is an alternate method that attempts to approximate what would be found if that proverbial perfect world existed.

The Young Center estimate of population growth is one way to view doubling time in Amish society. However, there are four other ways, each looking at growth from a different angle. The first is simply to calculate how rapidly new settlements are founded (minus those that become extinct); that is, to determine net settlement increase. This is an important consideration because it helps us understand the geographic spread of Amish settlements and the kinds of counties in which they are located.

A second way to calculate a doubling time is based on the number of households in various Amish settlements. Has this increased to the same extent as the Young Center estimate of the population's doubling time? If fertility rates (and death rates) have not changed much, then there should not be much difference between the doubling time of households and the doubling time of the population. The use of households has an added advantage because the doubling times of settlements based on their size (i.e., number of households) and age can be calculated and 
compared-even if particular settlements do not publish directories-through end-of-year statistics published in such periodicals as The Diary.

A third way to use doubling time to examine population change in Amish society is based on the increase in the number of church districts. At first glance, this may seem like a crude way to look at growth in Amish society, but it has significance because every church district has its own set of ordained men and its own church discipline or ordnung. Hence, doubling time as an expression of an increase in church districts has something to say about a possible increase in diversity of ordnungs, of possible new divisions, and the establishment of new fellowships or affiliations (Kraybill et al., 2013). Calculating a doubling time of church districts is straightforward because an annual publication known as Raber's Almanac or simply as Raber's (Raber, 2019) provides a nearly complete list of all church districts.

Finally, the listing of ordained men in Raber's Almanac is also an important way to examine doubling time and is corollary to the doubling time of church districts. How many more bishops,

ministers, and deacons are there today when compared to the past, and is their rate of increase similar to or different from how quickly the number of church districts has increased? Comparatively, is the doubling time of ordained men higher or lower than the doubling time of settlements and households?

\section{Doubling Time}

Doubling time is a measure of relative exponential growth, or the growth of something by a constant proportion that will double the size of the original number (Allendoerfer \& Oakley, 1955). Statistically, it can be expressed as $\mathrm{T}_{\mathrm{d}}=\left(\mathrm{t}_{2}-\mathrm{t}_{1}\right) * \log (2) / \log \left(\mathrm{q}_{2} / \mathrm{q}_{1}\right)$, where $\mathrm{T}_{\mathrm{d}}$ is the doubling time, $\mathrm{q}_{2}$ and $\mathrm{q}_{1}$ are the quantities at time $2\left(\mathrm{t}_{2}\right)$ and time $1\left(\mathrm{t}_{1}\right)$. Doubling time, therefore, is the number of standard time periods between time $2\left(\mathrm{t}_{2}\right)$ and time $1\left(\mathrm{t}_{1}\right)$ multiplied by the product of the logarithmic value for the number 2 (or twice as much) after it is divided by the logarithmic value derived from dividing a quantity at time 2 by a quantity at time 1 . This formula assumes that there is a positive increase from time 1 to time 2 and the percentage change across each time period is constant.

For most of us, a logarithm is one of the more difficult mathematical terms to understand intuitively. However, I remember a high school mathematics teacher explaining it with the analogy that if subtraction is the opposite of addition and division is the opposite of multiplication, then consider a logarithm as the opposite of the square of a number; that is, its exponential growth or exponent. So, if the logarithmic base is 10 , the logarithmic value of 100 is 2 , that is, $10 \times 10$. With a base 2 , the logarithmic value of 8 is 3 , or $2 \times 2 \times 2$, which is equal to $2^{3}$.

An approximation or shorthand for doubling time is known as the "rule of 72 " and is easier to understand because it can be used on an everyday basis without understanding logarithms. The rule of 72 says that 72 divided by a percentage increase creates a rough estimate of doubling time. Hence, if an investment of $\$ 100,000$ derives a dividend of $\$ 4,500$ in a single year, which represents a $4.5 \%$ gain, about 16 years will be required to double the investment given the same rate of return over those 16 years $(72 / 4.5=16)$. 


\section{Results}

\section{Doubling Time of Settlements}

The sociological definition of a community includes both a geographic and a social dimension (Liepins, 2000). In other words, a community is a specific place, nearly always with a name, where people interact by virtue of their physical proximity. The name itself may refer to a legal jurisdiction, such as a village, town, shire, or other entity as identified by the constitution of a province or state. Almost all Amish settlements founded since 1900 adopt the name of a nearby town with a post office and associated postal code of those Amish families who live there. For example, one of the newest Amish communities is known as Salmon, Idaho, the name of the nearby community that in turn has the same name as the Salmon River that runs through the state. In earlier times, an Amish community would often acquire a nickname associated with a wider geographic area, such as the settlements in Pennsylvania that are identified as "Penns Valley," "Nittany Valley," and "Brush Valley."

The geographic proximity of families helps create the sociological dimension of beliefs, values, and practices that define a group of people, especially distinctive groups within a large society, like the Amish. Perhaps the better word is "re-create" because many families are moving from an established Amish community to a new one. Hence, Hostetler (1993, p. 91) defined an Amish community or settlement as a "social grouping" in which "families living in a contiguous relationship...are in proximity to one another." Kraybill (1989, p. 11) described an Amish settlement as one that "encompasses the cluster of Amish families living in a common geographic area" and can range in size from a handful of families to thousands. Likewise, Luthy, in Amish Settlements Across America (2009), specified three conditions for a settlement to be counted in his series: (1) composed of at least three families, or two if one of them includes a man in the ministry; (2) able to hold a church service; and (3) forbids ownership of motor vehicles. Luthy also notes that "each new settlement will either soon grow or falter and disband" (p. 1). Amish settlements or communities range in size from a single church district of perhaps a dozen families at most to settlements with over 250 church districts with a variety of affiliations or fellowships, ranging from those that are considered very conservative to those that are viewed as very progressive (Kraybill et al., 2013, pp. 138-139).

These three definitions fit perfectly the idea that an Amish settlement includes both geography and the social networks that develop when people live close to each other. In turn, these two conditions are associated with nearly all sociological definitions of a community. For example, Liepins (2000) defines a community as the interplay of "spaces and structure," "meanings," and "practices." She goes on to explain how these elements are reciprocally related, creating six types of dynamics through networks of interaction: meanings legitimate practices; practices enable the circulation and the challenging of meanings; practices occur in spaces and through structures; spaces and structure affect how practices are actualized; spaces and structures enable the materialization of meaning; and meanings are embodied in spaces and structures (p. 30). Every community is an interplay of the material (spaces and structures) and non-material (practices and 
meanings) aspects of the culture of a society and of various distinctive groups within a larger society, like the Amish. Hence, when a new settlement is started, the space or locality selected is converted into a place, with economic, social, and cultural dimensions. A simple and obvious example of these dynamics is the placement of slow-moving-vehicle signs on a rural road where Amish families are clustered.

It is accepted, almost without question, that the Amish will always remain rural-located; that is, an Amish community will never exist within a city environment because of religious beliefs associated with horse-and-buggy travel, a larger proportion of men who farm and engage in other occupations more suitably located in a rural environment, and the greater sense of autonomy afforded by country living, even though urban sprawl, increased traffic, factories, and other aspects of what one thinks of as urban have a greater presence than they used to in many rural places where Amish communities exist today. ${ }^{3}$ This assertion and the reasons for it illustrate how the three elements of Liepins' (2000) conceptualization of a community are reciprocally related. Rural locations help maintain boundaries between the Amish and the mainstream related to religious beliefs or meanings and religion-based practices. Spaces and structures where Amish settlements develop take on distinctive visual and physical traits, from buggy-wheel marks on asphalt roads and leftovers from what horses eat, to corn shocks in fields, to sawmills and furniture factories and other facilities for Amish businesses, to signs advertising honey and eggs and other cottage industry commodities, with the disclaimer "no Sunday sales."

Based on continuous updates about newly founded settlements (and a few that became extinct), Table 1 displays the number of settlements, beginning in 1999 and continuing through the first two decades of the twenty-first century. The number of settlements increased nearly twofold, from 299 in 1999 to 584 in $2019 .{ }^{4}$ Calculated over that 20-year period, the constant annual percentage increase in settlements was +3.404 , with a doubling time of 20.71 years, an estimate very close to

\footnotetext{
${ }^{3}$ Those who are familiar with the diversity of Amish settlements will recognize that there is one that is urban-located. It is the Amish settlement of Pinecraft, Florida. It is large enough for Raber's to list two Amish church districts there. A number of people from Plain Mennonite backgrounds also live in this distinctive neighborhood of Sarasota. Pinecraft was founded in 1949, although its origins go back to the 1920s. It did not start off that way, but it is now surrounded completely by urban development in the Sarasota area. Pinecraft is also a popular place for vacationing during cold weather months by Amish from northern and midwestern states. In the Pinecraft settlement, there is no horse-and-buggy travel; the Amish there rely on two- and three-wheeled bicycles. Despite the distinctive features of Pinecraft, it fits the criteria specified by John Hostetler (1993), Don Kraybill (1989), and Dave Luthy (2009) and is counted as an Amish settlement.

${ }^{4}$ The list of settlements used for calculation of settlement doubling times varies slightly from the list found on the Amish Studies website (Young Center for Anabaptist and Pietist Studies, 2020b). I began tracking settlements many years ago, using the files of the Pathway Heritage Historical Library and correspondence with its owner, David Luthy. For example, on my list, one will find a conservative Amish settlement in Holmes County called Lakeville/Big Prairie only a few miles west of the Greater Holmes County settlement, which is not on the Young Center list. The discrepancy is due to differing ways of making decisions about what is a separate settlement and what is not a settlement. Regardless, the lists are at least $98 \%$ in agreement, and the difference would only slightly modify a doubling time calculation of settlements.
} 
the Young Center's 20-year doubling time for the population. Table 1 also shows increases in fiveyear increments, plus changes for each decade of the century. Even though there is some variation in the doubling times based on five-year statistics, the doubling times are nearly identical for each decade. If this pace of change continues - that is, using a constant annual percentage change of +3.404 - the number of Amish settlements will exceed 1,000 in 2036, and will be close to 1,600 by mid-century (see Table 7).

What are the possible implications of Amish settlement growth of this magnitude? Aside from a growing regional presence in states that previously had little or no Amish residents, such as Maine and Montana, there is the possibility that settlement growth will be a major driver of church discipline diversity. Because the Amish do not have a hierarchal structure or bureaucracy for standardization of church-based practices, it is likely that addressing issues associated with the new localities and their physical ecology will modify practices to some extent, especially in newly formed settlements. In addition, over time, as new settlements grow and mature, their autonomy as expressed through the ordnung will grow; that is, incrementally there will be greater and greater differences between new settlements and the communities from which families who migrated to these new places came. This can be seen in regard to the community near Hutchinson, Kansas, which allows tractors for farm work. Tractors are also advantageous for traveling into a market town and for hauling an improvised trailer converted for school bus purposes because the distance is too long during harsh winter months for children to walk to school (Kraybill et al., 2013). Hutchinson's practices are distinctive from most other settlements, in part because they are a reaction to the conditions imposed on them by "spaces and structures" (which include terrain and weather) found in that part of Kansas (Liepins, 2000).

The rapid increase in settlements also likely gives greater importance to the role of steering committees in addressing various issues associated with the Amish diaspora across North America. Steering committees emerged out of concerns in the 1960s about deferments for young men who applied for exemptions from military service, but have since addressed a wide variety of issues that are common across Amish communities and affiliations. These steering committees are organized on either a statewide basis or regionally (within a state or across several states, depending upon the number of settlements in an area). Men are appointed to these committees and serve without any financial compensation (Kraybill et al., 2013, pp. 358-359).

With Amish now in such unlikely places as Manitoba, Prince Edward Island, Colorado, Idaho, Vermont, and Wyoming, new challenges are met as the Amish deal with the enforcement of local ordinances that may conflict with their practices as encoded through the church ordnung. Steering committee members channel "grassroots concerns to the national committee and... explain new agreements with government officials to their hometown constituents" (Kraybill et al., 2013, p. 358). In this way, problem-solving is not piecemeal, but coordinated across multiple communities with similar issues.

As well, there are numerous other forms of coordinative social organization that help provide a degree of uniformity to Amish society, including, among others, periodic teachers' meetings, 
meetings of historians, and gatherings of men to discuss worker safety and other business issues associated with both farm and nonfarm enterprises. Without these coordinative forms of social organization, the Amish would likely devolve into a collection of several hundred small (and some large) communities with growing differences in practices and a weak common identity, even though all would still exhibit characteristics that mark them as distinctive from mainstream society. However, their future would be marked by much more divergence. In contrast, with these coordinative forms of social organization, the Amish will remain a collection of several hundred settlements with a common heritage, a stronger common identity, and, likely, a shared future.

\section{Table 1}

Settlement Growth: 1999-2019

\begin{tabular}{ccccc}
\hline Year & $\begin{array}{c}\text { Number of } \\
\text { Settlements }\end{array}$ & Time Period & $\begin{array}{c}\text { Constant Percentage } \\
\text { Change }\end{array}$ & $\begin{array}{c}\text { Doubling Time: } \\
\text { Years }\end{array}$ \\
\hline 1999 & 299 & $1999-2004$ & +3.03 & 23.28 \\
2004 & 347 & $2004-2009$ & +3.80 & 18.62 \\
2009 & 418 & $1999-2009$ & +3.41 & 20.69 \\
2014 & 486 & $2009-2014$ & +3.11 & 22.99 \\
2019 & 584 & $2014-2019$ & +3.75 & 18.87 \\
& & $2009-2019$ & +3.40 & 20.73 \\
& & $1999-2019$ & +3.40 & 20.71 \\
\hline
\end{tabular}

\section{Doubling Time and Households}

The Diary of the Old Order Churches is a monthly publication with the subtitle "A contribution of the church for the church by the church in the interest of collecting and preserving its historical virtues." It is one of many periodicals that publish news of events from various Amish settlements. ${ }^{5}$ Every month, reporters or scribes (a volunteer responsibility) write about events that occur in the community, such as the weather, how well farm crops and gardens are doing, births, deaths, accidents, school programs, visitors to the community, and church events. The Diary also includes "end-of-year statistics." These statistics are usually reported in the January issue, although some may be found in the December, February, and March issues. A typical entry can be illustrated by

\footnotetext{
${ }^{5}$ There are two other prominent Amish periodicals with national-level circulation in both Canada and the United States that also feature end-of-year statistics, including number of households. These are The Budget and Die Botschaft. The Budget has the largest circulation of the three and now owns The Diary. The Budget, a weekly publication that includes reports from various Amish and other Plain Anabaptist communities, is headquartered in Sugarcreek, Ohio, which is located on the eastern side of the Greater Holmes County settlement. The Budget began receiving reports of community events from Amish and Mennonite groups as far back as the 1880s. Die Botschaft ("The Message"), a weekly publication started in 1975, is a periodical in which reports from more conservative Amish are more likely to be published.
} 
a recent report from a settlement located in a northern state: "Statistics: 3 church districts, 62 households, 2 widows, 17 babies, 10 boys and 7 girls, 55 young folks, 6 schools, 2 weddings, 1 boy married in Canada and lives there."

By collecting the number of households in the settlements that report these statistics in consecutive years, it is possible to calculate a doubling time. Table 2 displays the results for communities with consecutive end-of-year statistics from 2009 through 2019 . This creates 10 pairs of years when the scribe for the same settlement reported the number of households. Many times, a scribe failed to mention these statistics for a particular year, which is the reason why the number of settlements varies from one set of consecutive years to the next in Table 2. For example, endof-year statistics were reported for 131 settlements in both 2009 and 2010, but for only 121 settlements in 2010 and 2011. Nonetheless, this creates 131 cases and 121 cases, respectively, where the number of households can be added up, and both the percentage change and the doubling time can be calculated. Altogether, there were 1,332 cases where an end-of-year statistics report was provided for consecutive years.

\section{Table 2}

Doubling Time Based on End-of-Year Statistics in The Diary

\begin{tabular}{ccccc}
\hline Time Period & $\begin{array}{c}\text { Number of } \\
\text { Settlements with } \\
\text { Consecutive } \\
\text { End-of-Year } \\
\text { Statistics }\end{array}$ & $\begin{array}{c}\text { Number of } \\
\text { Households } \\
\text { (q2/q1) }\end{array}$ & $\begin{array}{c}\text { Annual Percentage } \\
\text { Change }\end{array}$ & $\begin{array}{c}\text { Doubling Time: } \\
\text { Years }\end{array}$ \\
\hline $2010 / 2009$ & 131 & $7,359 / 7,122$ & +3.32 & 21.17 \\
$2011 / 2010$ & 121 & $6,136 / 5,972$ & +2.75 & 25.86 \\
$2012 / 2011$ & 136 & $7,274 / 6,987$ & +4.11 & 17.22 \\
$2013 / 2012$ & 138 & $7,599 / 7,312$ & +3.93 & 18.00 \\
$2014 / 2013$ & 138 & $7,777 / 7,496$ & +3.75 & 18.83 \\
$2015 / 2014$ & 133 & $7,958 / 7,595$ & +4.78 & 14.85 \\
$2016 / 2015$ & 126 & $7,741 / 7,369$ & +5.05 & 14.07 \\
$2017 / 2016$ & 146 & $8,842 / 8,453$ & +4.60 & 15.41 \\
$2018 / 2017$ & 134 & $8,177 / 7,844$ & +4.27 & 16.57 \\
$2019 / 2018$ & 129 & $6,949 / 6,769$ & +2.66 & 26.41 \\
$2014 / 2009$ & 664 & $36,145 / 34,889$ & +3.60 & 19.60 \\
$2019 / 2014$ & 668 & $39,667 / 38,030$ & +4.30 & 16.45 \\
$2019 / 2009$ & 1332 & $75,812 / 72,919$ & +3.97 & 17.82 \\
\hline
\end{tabular}


Unfortunately, it is impossible to calculate precisely the percentage of settlements that report consecutive-year statistics, but a ballpark estimate is that about $20 \%-25 \%$ of all settlements are represented. Also unfortunate is that a determination of the percentage of consecutive year statistics within various affiliations of Amish is not possible, particularly because communities that are more conservative are less likely to provide these statistics. Two prominent examples are the Swartzentruber settlements of Ethridge, Tennessee, and Heuvelton, New York, both of which now include 10 or more church districts.

Doubling time varied from one pair of years to the next. For example, the doubling time for 2015 (q1) and 2016 (q2) was a mere 14.07 years. The doubling time for 2018 (q1) and 2019 (q2) was 26.41 years. More stability is provided through weighted averages (based on the number of cases for each pair of years) for five-years intervals, and for the complete span of 10 years. These numbers are found in the bottom half of Table 2. From 2009 to 2014, the doubling time was 19.60 years, and it decreased to 16.45 years for the time period of 2014 to 2019 . Over the 10 years, the doubling time for households was 17.82 years.

The doubling time calculated from end-of-year statistics found in The Diary is lower than both the doubling time of settlements and the doubling time of the Amish population as determined by the Young Center. There is a reason for this. Table 2 shows statistics mostly for smaller settlements, which also tend to be newer settlements. These smaller settlements likely are growing faster because families from larger communities are moving to them. Hence, a combination of continued large-sized families and net in-migration accounts for a smaller doubling time.

One caution about out-migration from older and larger settlements to newer and smaller settlements is to avoid the misperception that the former are not thriving. In fact, nearly all settlements are gaining population, but due to a variety of reasons, from land prices to purposive founding of "daughter" and "outreach" communities, older and larger settlements play an important function in new settlement start-up and the maintenance of networks between families in new places and their parents and grandparents at the older locality. This is not an uncommon feature of immigration; people who move from one country to another will often use a hyphenated label for identification, such as "Italian-American" or "Mexican-American," communicate with and visit relatives and friends in the country they left, and host visitors from that country.

The top part of Table 3 breaks down these same settlements with fewer than 100 households with consecutive-year statistics by size and year founded. The doubling times of smaller settlements during the second decade of the twentieth century was less than half the doubling times of larger settlements. In other words, they are growing at least twice as fast. Given the number of cases (721), this is clearly a general pattern of population growth among smaller settlements, a finding reinforced by the bottom half of Table 3, which displays doubling times by the age of settlements. The differences in doubling time there are even more dramatic. Settlements founded before 1980 show doubling times that exceed 40 years, while those founded in the 1980s and 1990s have doubling times that are about half as large, and those settlements which began in the twentyfirst century show doubling times at a rate slightly over eight years. 
The populations of the twelve largest Amish communities are listed on the Young Center's Amish Studies website (2020c). Other than size, the reason for calculating the doubling times of large settlements is that end-of-year statistics in The Diary generally are not provided by the number of households since nearly all of those settlements have their own directories and it would be difficult for a single volunteer scribe to keep an accurate count of a settlement with hundreds and even thousands of households. In fact, nearly all publish directories on a regular basis that allow for calculation of doubling times, based on changes in the number of households from the time of one published directory to the next edition of the directory.

Table 4 shows how much these largest settlements are gaining population. The column titled "time period" refers to dates of directories at the beginning (q1) and end (q2). A 20-year period for doubling time calculations was preferred, such as with the Greater Holmes County and the Greater Geauga County settlements, but not always possible. Also, in between the q1 and q2 dates listed in Table 4, other directories were published. For example, there are three directories for the Greater Lancaster County settlement (1996, 2002, and 2016) and four directories for the ElkhartLaGrange-Noble Counties settlements (2002, 2007, 2012, 2017).

\section{Table 3}

Characteristics of Smaller Settlements and Doubling Time

\begin{tabular}{cccccc}
\hline Characteristic & $\begin{array}{c}\text { Number of } \\
\text { Time Period } \\
\text { (q2/q1) }\end{array}$ & $\begin{array}{c}\text { Settlements with } \\
\text { Consecutive } \\
\text { End-of-Year } \\
\text { Statistics }\end{array}$ & $\begin{array}{c}\text { Number of } \\
\text { Households } \\
\text { (q2/q1) }\end{array}$ & $\begin{array}{c}\text { Annual } \\
\text { Percentage } \\
\text { Change }\end{array}$ & $\begin{array}{c}\text { Doubling } \\
\text { Time: } \\
\text { Years }\end{array}$ \\
\hline < 50 Households & $2014 / 2009$ & 312 & $6,779 / 6,366$ & +6.49 & 11.03 \\
& $2019-2014$ & 409 & $11,137 / 10,440$ & +6.68 & 10.73 \\
$\geq 50$ Households & $2019-2009$ & 721 & $17,916 / 16,806$ & +6.66 & 10.84 \\
& $2014 / 2009$ & 225 & $23,494 / 22,946$ & +1.24 & 29.37 \\
Founded before 1980 & $2019-2014$ & 260 & $28,508 / 27,605$ & +3.27 & 21.53 \\
& $2019-2009$ & 485 & $52,002 / 5,0551$ & +2.87 & 24.93 \\
Founded in 1980s or & $2014 / 2009$ & 147 & $13,690 / 13,500$ & +1.41 & 49.60 \\
1990s & $2019-2014$ & 123 & $12,715 / 12,478$ & +1.90 & 36.84 \\
& $2019-2009$ & 270 & $26,405 / 25,978$ & +1.64 & 42.52 \\
Founded in 21st & $2014 / 2009$ & 269 & $13,671 / 13,244$ & +3.22 & 21.84 \\
century & $2019-2014$ & 223 & $14,577 / 13,877$ & +5.04 & 14.08 \\
& $2019-2009$ & 492 & $28,248 / 27,121$ & +4.16 & 17.02 \\
& $2014 / 2009$ & 231 & $5,715 / 5,234$ & +9.19 & 7.88 \\
& $2019-2014$ & 321 & $9,936 / 9,143$ & +8.67 & 8.33 \\
& $2019-2009$ & 552 & $15,651 / 14,377$ & +8.86 & 8.16 \\
\hline
\end{tabular}

The table in the appendix displays doubling times across all the time periods represented by the date of publication for recent editions of directories for these 11 largest settlements. Of particular note is that two different directories were required for estimating the doubling time of 
the Belleville/Reedsville, Pennsylvania, settlement, because the conservative Nebraska group publishes its own directory separate from the directory listing households for the Old Order and Byler Amish.

In general, these large settlements take a longer time to double in size, with the exception of the Swiss Amish settlement of Seymour in southern Missouri. Other large Swiss settlementsAdams-Jay Counties, Indiana, and Grabill/New Haven, Indiana—also display higher growth; that is, lower doubling times. Swiss Amish tend to have larger families, which likely accounts for their more rapid population growth, although they too are the locations from which families migrate out to newer and smaller settlements, almost always with Swiss Amish identity.

\section{Table 4}

Doubling Time of Largest Settlements

\begin{tabular}{lccc}
\hline Name of Settlement & $\begin{array}{c}\text { Time Period } \\
(\mathrm{q} 2-\mathrm{q} 1)\end{array}$ & $\begin{array}{c}\text { Constant Annual } \\
\text { Percentage } \\
\text { Change }\end{array}$ & $\begin{array}{c}\text { Doubling Time: } \\
\text { Years }\end{array}$ \\
\hline Greater Lancaster County, Pennsylvania & $2015-1996$ & +3.20 & 21.99 \\
Greater Holmes County, Ohio & $2020-2000$ & +2.13 & 32.83 \\
Elkhart-LaGrange-Noble Counties, Indiana & $2017-2002$ & +3.02 & 23.30 \\
Greater Geauga County, Ohio & $2018-1998$ & +3.36 & 20.96 \\
Adams-Jay Counties, Indiana & $2018-1992$ & +3.24 & 21.74 \\
Nappanee, Indiana & $2020-2001$ & +2.32 & 30.24 \\
Belleville/Reedsville, Pennsylvania & $2017-2007$ & +2.47 & 28.39 \\
Arthur/Arcola, Illinois & $2020-1993$ & +1.26 & 55.37 \\
Montgomery/Odon, Indiana & $2015-1996$ & +3.11 & 22.66 \\
Grabil/New Haven, Indiana & $2020-2000$ & +3.11 & 22.61 \\
Seymour, Missouri & $2016-1996$ & +4.69 & 15.11 \\
\hline
\end{tabular}

The differences in doubling times across 10 of these 11 settlements is small. Doubling times are larger for the Greater Holmes County settlement (32.83 years) and the Nappanee settlement (30.24 years), and smaller for Greater Lancaster County (21.99 years), Montgomery/Odon (22.66 years), and the three Swiss Amish settlements. The population of Arthur/Arcola is growing the least and is the outlier in Table 4, with a doubling time much larger than the others (55.37 years). Likely, this is a combination of both smaller families and greater out-migration.

Examining doubling times based on changes in the number of households (Tables 2, 3, and 4) indicates a rate of growth commensurate with the increase in new settlements (Table 1). Younger and smaller settlements display higher growth, relieving at least some of the pressure on population growth in the older and larger settlements. Hence, all types of Amish settlements are growing and there is no indication that growth will dramatically slow down over the next several decades. For 
the rate of growth to decline would require a change in one or both of two conditions. First, doubling times can increase by a decline of natural growth through a decline in fertility and smaller family sizes. There is some evidence that fertility rates, and therefore, family size, are declining very gradually (Greksa, 2002; Kraybill et al., 2013). If this is true, then calculating similar doubling times over the next several decades will display slowly rising or larger doubling times. Second, analogous to the idea of net migration (the number of people who move to an area vs. the number who move out), either a reduction in the percentage of young people who decide not to be baptized Amish or a major schism in which a great many Amish no longer identify themselves as Amish would have to occur, as it did over the many decades after the ministers' meetings of the midnineteenth century (Nolt, 2015).

\section{Doubling Time, Church Districts, and Ordained Men}

The final way to examine doubling time is based on the Amish church. Table 5 shows the doubling time for church districts, and Table 6 summarizes the doubling time of ordained men, which is further broken down by the three positions of bishop, minister, and deacon. The information for calculating these doubling times comes from The New American Almanac, known more popularly as Raber's Almanac or simply Raber's. Raber's began publication in 1930 and from its first issue, published in German, it included astrological information associated with phases of the moon and the position of planets for every month of the year, Bible verses, and Christian feast days, plus a list of Amish church districts and the names and addresses of ordained men. Raber's got its nickname from the family who publishes the almanac and Raber's Bookstore, the establishment they operate in Baltic, Ohio, which is located on the southern end of the Greater Holmes County settlement.

In its second volume, published in 1931, information on 112 church districts was included, occupying a total of five pages. By its fifty-first English language edition, published in 2020, there were slightly over 2,450 church districts listed on 73 pages of text. Church districts are listed by state, and within state, by county. Almost all church districts comprise 20 to 40 families (Kraybill et al., 2013). Once a church district becomes too large, it divides into two church districts, followed by the ordination of a new bishop, minister, and deacon so that both congregations have a full complement of church leaders. Several of these divisions are announced in every issue of periodicals such as The Diary.

It should be noted that the listing of church districts and ordained men is not $100 \%$ complete, although it is nearly so. Sometimes the single church district of a new settlement cannot be found in Raber's, and for a few church districts, no information is provided.

Table 5 shows the doubling times of church districts from 2000 through 2020. The doubling time was 19.29 years, which matches closely the doubling time estimate of the Amish population by the Young Center (2020a). Doubling time was slightly lower for the first decade (18.70 years)

of the twenty-first century than for the second decade (19.91 years). Regardless of these small 
variations, the numbers in Table 5 indicate that more than half of all Amish church districts were created in the twenty-first, not the twentieth, century or earlier.

Church districts are increasing at a faster pace than settlements, reflecting the growth of households across all settlements and the need for creating new church districts in settlements both large and small, and young and old. Given the fast pace at which settlements founded in the twentyfirst century have increased their number of households, the doubling time of church districts should not be surprising. Therefore, so long as the number of households that compose a single church district does not dramatically increase in size (Kraybill et al., 2013), all three features of Amish social organization - settlements, households, and church districts - will increase at about the same pace. It is likely that more conservative affiliations of Amish, because of their larger families (Kraybill et al., 2013, pp. 156-157), have smaller doubling times, whether calculated by the number of settlements, the number of households, the number of church districts, or the number of ordained men. Although beyond the scope of this paper, it does suggest the direction of future research: doubling time differences by affiliation.

\section{Table 5}

Church Districts and Doubling Time

\begin{tabular}{ccccc}
\hline Year & $\begin{array}{c}\text { Number of Church } \\
\text { Districts }\end{array}$ & $\begin{array}{c}\text { Time Period } \\
(\mathrm{q} 2-\mathrm{q} 1)\end{array}$ & $\begin{array}{c}\text { Constant Percentage } \\
\text { Change }\end{array}$ & $\begin{array}{c}\text { Doubling Time: } \\
\text { Years }\end{array}$ \\
\hline 2000 & 1,197 & & & \\
2010 & 1,734 & $2010-2000$ & +3.78 & 18.70 \\
2020 & 2,456 & $2020-2010$ & +3.54 & 19.91 \\
& & $2020-2000$ & +3.66 & 19.29 \\
\hline
\end{tabular}

Table 6 displays the doubling time of ordained men in total, and then broken down by the three leadership positions of bishop, minister, and deacon. During the first two decades of the twentyfirst century, the doubling time for all ordained men was actually slightly lower than the doubling time of church districts. Even though the differences are not very large, doubling time is lowest for deacons, slightly higher for bishops, and highest for ministers. It is difficult to discern if the lower doubling time for deacons is an indicator of their growing importance within Amish society, but it is indeed worth watching in terms of its implications for change in Amish society via churches.

Like church districts, there are now more Amish men who were ordained in the twenty-first than in the twentieth century. Is this a harbinger of change? Many more ordained men now provide leadership in newer and smaller settlements that are more geographically dispersed. Further, a majority of bishops, ministers, and deacons were ordained during times when, in most settlements, farming was no longer what the majority of men do to make a living for their families (Kraybill et al., 2013). 
Table 6

Doubling Time of Ordained Men

\begin{tabular}{|c|c|c|c|c|c|}
\hline & Year & Total & $\begin{array}{l}\text { Time Period } \\
\text { (q2-q1) }\end{array}$ & $\begin{array}{c}\text { Constant } \\
\text { Percentage } \\
\text { Change }\end{array}$ & $\begin{array}{l}\text { Doubling } \\
\text { Time: } \\
\text { Years }\end{array}$ \\
\hline All Ordained Men & $\begin{array}{l}2000 \\
2010 \\
2020\end{array}$ & $\begin{array}{l}4,507 \\
6,834 \\
9,758\end{array}$ & $\begin{array}{l}2010-2000 \\
2020-2010 \\
2020-2000\end{array}$ & $\begin{array}{l}+4.25 \\
+3.62 \\
+3.94\end{array}$ & $\begin{array}{l}16.65 \\
19.46 \\
17.95\end{array}$ \\
\hline Bishops & $\begin{array}{l}2000 \\
2010 \\
2020\end{array}$ & $\begin{array}{r}970 \\
1,501 \\
2,197\end{array}$ & $\begin{array}{l}2010-2000 \\
2020-2010 \\
2020-2000\end{array}$ & $\begin{array}{l}+4.46 \\
+3.89 \\
+4.17\end{array}$ & $\begin{array}{l}15.88 \\
18.19 \\
16.96\end{array}$ \\
\hline Ministers & $\begin{array}{l}2000 \\
2010 \\
2020\end{array}$ & $\begin{array}{l}2,546 \\
3,795 \\
5,263\end{array}$ & $\begin{array}{l}2010-2000 \\
2020-2010 \\
2020-2000\end{array}$ & $\begin{array}{l}+4.07 \\
+3.32 \\
+3.70\end{array}$ & $\begin{array}{l}17.37 \\
21.20 \\
19.09\end{array}$ \\
\hline Deacons & $\begin{array}{l}2000 \\
2010 \\
2020\end{array}$ & $\begin{array}{r}991 \\
1,538 \\
2,298\end{array}$ & $\begin{array}{l}2010-2000 \\
2020-2010 \\
2020-2000\end{array}$ & $\begin{array}{l}+4.49 \\
+4.10 \\
+4.30\end{array}$ & $\begin{array}{l}15.77 \\
17.26 \\
16.48\end{array}$ \\
\hline
\end{tabular}

\section{Summary, Conclusions, and Recommendations}

The purpose of this article was to examine the doubling time of the Amish from a variety of angles, including settlements, households, church districts, and ordained men. All the calculations are in line with the Young Center estimate that the Amish population doubles about every 20 years (2020a), given current family size and baptism rates. All four doubling times discussed in this article, plus the Young Center estimate, are moving in the same direction, which is a rapid increase in both the Amish population and major social organizational features of Amish society.

Nonetheless, there was variation in the doubling time numbers. Most significantly, the doubling time for settlements founded in the twenty-first century, based on the reported number of households from end-of-year statistics in The Diary, was much smaller. This is not an unexpected finding, since most newly formed settlements grow rapidly, or likely become extinct if there are not enough households there to ordain their own church leaders and sustain their community life.

The statistics presented in these six tables show that where doubling times could be calculated for the periods 2000-2010 and 2010-2020, variations were minor. Hence, a conclusion from two decades of sustained rapid growth in the twenty-first century suggests several more decades of sustained rapid growth. Table 7 projects this conclusion into the future, statistically speaking. As mentioned previously, sustained annual settlement growth of +3.40 means there will be nearly 1,600 separate Amish communities by the year 2050. ${ }^{6}$ The statistics for households is not comprehensive for all Amish settlements. As a substitute, the Young Center's Amish Studies

\footnotetext{
${ }^{6}$ Although percentage change is shown with only two digits to the right of the decimal point, the calculations in Table 7 were based on five digits to the right of the decimal point.
} 
website estimates a total of 344,760 individuals in the United States today and a doubling time of 20 years, which is a constant annual percentage change of +3.53 (2020a). If this annual percentage increase remains unchanged, the projection is that the Amish population will be about 487,400 by $2030 ; 689,300$ by 2040 ; and 944,750 by 2050 . With a constant annual percentage increase of +3.66 , the number of church districts will grow from the 2,456 listed in the 2020 edition of Raber's to 3,518 by $2030 ; 5,040$ by 2040 ; and 7,220 by mid-century. The number of ordained men will likewise grow, assuming a constant annual percentage increase of +3.94 , from the 9,758 listed in the 2020 version of Raber's to 14,361 by $2030 ; 21,136$ by 2040 ; and 31,106 by $2050 .^{7}$

Clearly, projections like these show why demographic studies of the Amish are very important for understanding the group's future and how these changes will impact its social and cultural dimensions. To make a visual analogy, the demographic features of the Amish form the foundation of their society, much like the foundation of a tall structure, such as a skyscraper or a pyramid. Will these doubling times be altered radically or, as the evidence from the first two decades of the twenty-first century suggest, either remain about the same or shift very gradually? If the latter is correct, how will these projected numbers be the sources of possible change in Amish society? Briefly, two scenarios are proposed. The first is that these kinds of increases in settlements, households, church districts, and ordained men will create so much diversity that a series of schisms will occur, with the possibility that one of the sides will no longer wish to identify as Amish. The division of Amish in the mid-nineteenth century, for example, was expressed partially on the basis of location, with more progressive Amish tending to be from settlements to the west of Pennsylvania and Ohio, where more conservative settlements were located (Nolt, 2015). As Amish settlements expand their geographic reach, from the U.S. state of Montana to the Canadian provinces of Manitoba and Prince Edward Island, perhaps a similar division, with clear geographic dimensions, will mark the history of the Amish in the twenty-first century.

The second scenario proposes that the Amish of 2050 will look much like the Amish of today, who already exhibit a great deal of diversity, but likely with even more diversity as new affiliations of Amish are formed concomitantly with growth in the number of settlements and the regional spread of Amish communities into new regions of Canada and the United States. What is likely to change - what makes this second scenario a real possibility because it is already happening-is the growing importance of steering committees and other kinds of coordinative organizational structures that address common problems and propose common solutions, especially on issues where the Amish must negotiate and compromise with local, state, and national governments (Kraybill et al., 2013).

The National Amish Steering Committee and various state/regional steering committees emerged in the 1960s, and since then, have grown in prominence. Recently, for example, they issued guidelines for Amish on when and how to hold church services and whether or not to

\footnotetext{
${ }^{7}$ Sharing projections like those found in Table 7 with colleagues in the past elicited two distinctive oneword exclamations. They are "breathtaking" or "frightening." The former refers to how unexpectedly fast the Amish are growing, while the latter considers the potential impacts of these changes on their society.
} 
continue the operation of schools with the outbreak of the COVID-19 pandemic. Steering committees and other kinds of coordinative organizational structures, such as those associated with business interests, will help maintain and perhaps even strengthen the horizontal integration of a rapidly growing Amish population and an ever-expanding number of settlements. ${ }^{8}$

As well, aspects of Amish society associated with socialization, such as schools, school curriculum, and teacher meetings, will grow in importance and centrality if the current retention rate in the Amish faith remains high. To quote one scribe writing in a recent edition of The Diary, "You teachers probably don't realize the responsibility you carry. Trouble in school will likely show itself again in church later. So, parents, let us help our teachers and school board." Similar coordinative structures can be found in periodic meetings on history and many other issues.

All cultures seek to reproduce themselves from one generation to the next. Some perform this function more successfully than others. Often, rapid change reduces this success. Amish society is changing rapidly, at least in terms of the growth of its population, its settlements, its church districts, and its ordained men. Yet, there is much that has not changed (Kraybill et al., 2013). No matter if this growth creates relatively little or relatively large change, putting a quantitative face on this growth will help future scholars understand important modifications of the cultural and social dimensions of Amish society.

Table 7

Doubling Times and Projections

\begin{tabular}{lrrrc}
\hline & \multicolumn{4}{c}{ Year } \\
\cline { 2 - 5 } \multicolumn{1}{c}{ Feature } & 2020 & 2030 & 2040 & 2050 \\
\hline $\begin{array}{l}\text { Settlements constant annual } \\
\text { percentage change: +3.40 }\end{array}$ & 594 & 816 & 1,141 & 1,594 \\
$\begin{array}{l}\text { Population constant annual } \\
\text { percentage change: +3.53 }\end{array}$ & 344,767 & 487,417 & 689,282 & 944,752 \\
$\begin{array}{l}\text { Church districts constant annual } \\
\text { percentage change: +3.6 }\end{array}$ & 2,456 & 3,518 & 5,040 & 7,220 \\
$\begin{array}{l}\text { Ordained men constant annual } \\
\text { percentage change: +3.94 }\end{array}$ & 9,758 & 14,361 & 21,136 & 31,106 \\
\hline
\end{tabular}

${ }^{8}$ In classic (mid-twentieth century) literature on the sociology of the community, a distinction is made between vertical integration and horizontal integration (Warren, 1963). The former refers to a strengthening of links between a community and various outside organizations, especially government entities at the provincial/state and federal government levels and church and business entities whose headquarters are located somewhere else but have local branches. Horizontal integration refers to a strengthening of links among people living in the same area, such as in an urban neighborhood or different neighborhoods or suburbs in the same metropolitan area. In the discussion for this article, horizontal integration is modified to refer to a strengthening of organizations that tie together different Amish communities with common problems to solve, such as when the National Amish Steering Committee or state/regional steering committees address regulations on schooling or workplace safety. 


\section{References}

Allendoerfer, C. B., \& Oakley, C. O. (1955). Principles of mathematics. McGraw-Hill Book Company, Inc.

Bogue, D. (1969). Principles of demography. John Wiley and Sons.

Cross, H. E. (1976). Population studies and the Old Order Amish. Nature, 262, 17-20. https://doi.org/10.1038/262017a0

Cross, H. E., \& McKusick, V. A. (1970). Amish demography. Social Biology, 17(2), 83-101. https://doi.org/10.1080/19485565.1970.9987850

Ericksen, E. P., Ericksen, J. A., \& Hostetler, J. A. (1980). The cultivation of the soil as a moral directive: Population growth, family ties, and the maintenance of community among the Old Order Amish. Rural Sociology, 45(1), 49-68.

Ericksen, J. A., Ericksen, E. P., Hostetler, J. A., \& Huntington, G. E. (1979). Fertility patterns and trends among the Old Order Amish. Population Studies, 33(2), 255-276. https://doi.org/10.1080/00324728.1979.10410441

Greksa, L. P. (2002). Population growth and fertility patterns in an Old Order Amish settlement. Annals of Human Biology, 29(2), 192-201. https://doi.org/10.1080/03014460110075684

Greksa, L. P. (2004). Birth seasonality in the Old Order Amish. Journal of Biosocial Science, 36(3), 299-315. https://doi.org/10.1017/S0021932003006254

Greksa, L. P., \& Korbin, J. E. (2002). Key decisions in the lives of the Old Order Amish: Joining the church and migrating to another settlement. Mennonite Quarterly Review, 76(4), 373-398.

Hostetler, J. (1993). Amish society. (4th ed.). Johns Hopkins University Press.

Kraybill, D. (1989). The riddle of Amish culture. Johns Hopkins University Press.

Kraybill, D., Johnson-Weiner, K., \& Nolt, S. (2013). The Amish. Johns Hopkins University Press.

Liepins, R. (2000). New energies for an old idea: Reworking approaches to 'community' in contemporary rural studies. Journal of Rural Studies, 16(1), 23-35.

https://doi.org/10.1016/S0743-0167(99)00042-X

Luthy, D. (2009). Amish settlements across America: 2008. Pathway Publishers.

Markle, G. E., \& Pasco, S. (1977). Family limitation among the Old Order Amish. Population Studies, 31(2), 267-280. https://doi.org/10.2307/2173918

Meyers, T. J. (1991). Population growth and its consequences in the Elkhart-LaGrange Old Order Amish settlement. Mennonite Quarterly Review, 65(3), 308-321.

Meyers, T. J. (1994). The Old Order Amish: To remain in the faith or to leave. Mennonite Quarterly Review, 68(3), 378-395.

Nolt, S. M. (2015). A history of the Amish. (3rd ed.). Good Books.

Raber, A. B. (2020). The new American almanac. (51st ed.). Aden B. Raber.

Smith, E. L. (1960). Studies in Amish demography. Research Council of Eastern Mennonite College.

Warren, R. L. (1963). The community in America. Rand McNally \& Co. 
Wasao, S. W., \& Donnermeyer, J. F. (1996). An analysis of factors related to parity among the Amish in Northeast Ohio. Population Studies, 50(2), 235-246. https://doi.org/10.1080/0032472031000149326

Wood, J. W., Holman, D. J., Yashin, A. I., Peterson, R. J., Weinstein, M., \& Chang, M.-C. (1994). A multistate model of fecundability and sterility. Demography, 31, 403-426. https://doi.org/10.2307/2061750

World Bank. (n.d.). Population growth (annual \%). Retrieved October 10, 2020, from https://data.worldbank.org/indicator/SP.POP.GROW

Young Center for Anabaptist and Pietist Studies. (2020a). Amish population, 2020. Amish Studies. Retrieved October 18, 2020, from http://groups.etown.edu/amishstudies/statistics/statistics-population-2020/

Young Center for Anabaptist and Pietist Studies. (2020b). Amish population by state and county. Amish Studies. Retrieved October 10, 2020, from https://groups.etown.edu/amishstudies/files/2020/10/Amish_Pop_by_state_and_county_2020 .pdf

Young Center for Anabaptist and Pietist Studies. (2020c). Twelve largest settlements, 2020. Amish Studies. Retrieved October 5, 2020, from http://groups.etown.edu/amishstudies/statistics/twelve-largest-settlements-2020/ 


\section{Appendix}

Settlement Growth by Number of Households for Largest Settlements*

\begin{tabular}{|c|c|c|c|c|}
\hline Name of Settlement & $\begin{array}{c}\text { Year of } \\
\text { Directories / } \\
\text { Time Period }\end{array}$ & $\begin{array}{l}\text { Number of } \\
\text { Households }\end{array}$ & $\begin{array}{l}\text { Constant Annual } \\
\text { Percentage Change from } \\
\text { Previous Directory } \\
\text { (number of years: q2-q1) }\end{array}$ & $\begin{array}{l}\text { Doubling } \\
\text { Time: } \\
\text { Years }\end{array}$ \\
\hline $\begin{array}{l}\text { Greater Lancaster County, } \\
\text { Pennsylvania }\end{array}$ & $\begin{array}{c}1996 \\
2002 \\
2015 \\
2015-1996 \\
\end{array}$ & $\begin{array}{l}3,534 \\
4,632 \\
6,433 \\
------ \\
\end{array}$ & $\begin{array}{l} \\
+--6 .-- \\
+21(6) \\
+2.80(13) \\
+3.20(19)\end{array}$ & $\begin{array}{l}------ \\
15.37 \\
27.43 \\
21.99\end{array}$ \\
\hline $\begin{array}{l}\text { Greater Holmes County, } \\
\text { Ohio }\end{array}$ & $\begin{array}{c}2000 \\
2005 \\
2010 \\
2015 \\
2020 \\
2010-2000 \\
2020-2010 \\
2020-2000\end{array}$ & $\begin{array}{l}4,844 \\
5,299 \\
5,839 \\
6,550 \\
7,389 \\
------ \\
------\end{array}$ & $\begin{array}{l}+----- \\
+1.81(5) \\
+1.96(5) \\
+2.32(5) \\
+2.44(5) \\
+1.19(10) \\
+2.38(10) \\
+2.13(20)\end{array}$ & $\begin{array}{l}----- \\
38.60 \\
35.71 \\
30.16 \\
28.75 \\
37.10 \\
29.44 \\
32.83\end{array}$ \\
\hline $\begin{array}{l}\text { Elkhart-LaGrange-Noble } \\
\text { Counties, Indiana }\end{array}$ & $\begin{array}{c}2002 \\
2007 \\
2012 \\
2017 \\
2017-2007 \\
2017-2002\end{array}$ & $\begin{array}{l}3,349 \\
3,609 \\
4,488 \\
5,233 \\
------ \\
-----\end{array}$ & $\begin{array}{l}+----- \\
+1.73(5) \\
+4.46(5) \\
+3.12(5) \\
+3.79(10) \\
+3.02(15)\end{array}$ & $\begin{array}{l}----- \\
46.35 \\
15.90 \\
22.57 \\
18.66 \\
23.30\end{array}$ \\
\hline $\begin{array}{l}\text { Greater Geauga County, } \\
\text { Ohio }\end{array}$ & $\begin{array}{c}1998 \\
2001 \\
2009 \\
2014 \\
2018 \\
2009-1998 \\
2018-2009 \\
2018-1998\end{array}$ & $\begin{array}{l}1,817 \\
2,123 \\
2,614 \\
2,977 \\
3,520 \\
------- \\
-------\end{array}$ & $\begin{array}{c}------ \\
+5.33(3) \\
+4.25(8) \\
+2.64(5) \\
+4.28(4) \\
+3.36(11) \\
+3.36(9) \\
+3.36 \%(20)\end{array}$ & $\begin{array}{l}----- \\
13.36 \\
26.65 \\
26.65 \\
16.54 \\
20.96 \\
20.96 \\
20.96\end{array}$ \\
\hline $\begin{array}{l}\text { Adams-Jay Counties, } \\
\text { Indiana }\end{array}$ & $\begin{array}{c}1992 \\
2002 \\
2008 \\
2013 \\
2018 \\
2008-1992 \\
2018-2002 \\
2018-2008 \\
2018-1992\end{array}$ & $\begin{array}{r}666 \\
919 \\
1,183 \\
1,312 \\
1,526 \\
------ \\
----- \\
----- \\
-----\end{array}$ & $\begin{array}{l}+----- \\
+3.28(10) \\
+4.30(6) \\
+2.10(5) \\
+3.07(5) \\
+3.66(16) \\
+3.22(16) \\
+2.58(10) \\
+3.24(26)\end{array}$ & $\begin{array}{l}---- \\
21.53 \\
16.47 \\
33.49 \\
22.93 \\
19.30 \\
21.87 \\
27.23 \\
21.74\end{array}$ \\
\hline Nappanee, Indiana & $\begin{array}{c}2001 \\
2008 \\
2015 \\
2020 \\
2015-2001 \\
2020-2008 \\
2020-2001\end{array}$ & $\begin{array}{r}898 \\
1,046 \\
1,170 \\
1,388 \\
------- \\
------ \\
------\end{array}$ & $\begin{array}{l}\text {----- } \\
+2.21(7) \\
+1.62(7) \\
+3.48(5) \\
+1.91(14) \\
+2.39(12) \\
+2.32(19)\end{array}$ & $\begin{array}{l}------ \\
31.80 \\
43.31 \\
20.28 \\
36.68 \\
29.40 \\
30.24\end{array}$ \\
\hline
\end{tabular}




\begin{tabular}{|c|c|c|c|c|}
\hline Name of Settlement & $\begin{array}{c}\text { Year of } \\
\text { Directories / } \\
\text { Time Period }\end{array}$ & $\begin{array}{l}\text { Number of } \\
\text { Households }\end{array}$ & $\begin{array}{l}\text { Constant Annual } \\
\text { Percentage Change from } \\
\text { Previous Directory } \\
\text { (number of years: q2-q1) }\end{array}$ & $\begin{array}{l}\text { Doubling } \\
\text { Time } \\
\text { (in years) }\end{array}$ \\
\hline \multicolumn{5}{|l|}{$\begin{array}{l}\text { Belleville/Reedsville, } \\
\text { Pennsylvania }\end{array}$} \\
\hline \multirow[t]{3}{*}{ Nebraska Directory } & 2007 & 244 & ------- & ------- \\
\hline & 2011 & 283 & $+3.78(4)$ & 18.70 \\
\hline & 2017 & 329 & $+2.54(6)$ & 27.61 \\
\hline \multirow[t]{3}{*}{ Old Order Directory } & 2002 & 328 & ------ & ------ \\
\hline & 2007 & 349 & $+1.25(5)$ & 55.85 \\
\hline & 2017 & 428 & $+2.06(10)$ & 33.97 \\
\hline \multirow[t]{2}{*}{ Combined } & 2007 & 593 & ------- & ------- \\
\hline & 2017 & 757 & $+2.47(10)$ & 28.39 \\
\hline \multirow[t]{4}{*}{ Arthur/Arcola, Illinois } & 2003 & 765 & ------ & ------ \\
\hline & 2012 & 827 & $+0.87(9)$ & 80.05 \\
\hline & 2020 & 931 & +1.49 (8) & 46.81 \\
\hline & 2020-2003 & ------- & $+1.62(17)$ & 60.00 \\
\hline \multirow{7}{*}{$\begin{array}{l}\text { Montgomery/Odon, } \\
\text { Indiana** }\end{array}$} & 1994 & 539 & ------- & ------- \\
\hline & 2009 & 862 & +3.18 (15) & 22.14 \\
\hline & 2014 & 985 & $+2.71(5)$ & 25.98 \\
\hline & 2019 & 1,158 & +3.29 (5) & 21.42 \\
\hline & 2014-1994 & ------ & +3.06 (20) & 22.99 \\
\hline & 2019-2009 & ------- & +3.00 (10) & 23.48 \\
\hline & 2019-1994 & ------- & $+3.11(25)$ & 22.66 \\
\hline \multirow[t]{4}{*}{ Grabil/New Haven, Indiana } & 1990 & 408 & ------- & ------- \\
\hline & 2000 & 667 & $+5.18(10)$ & 14.10 \\
\hline & 2015 & 878 & +1.85 (15) & 37.83 \\
\hline & 2015-1990 & ------- & +3.11 (25) & 22.61 \\
\hline \multirow[t]{9}{*}{ Seymour, Missouri } & 1996 & 149 & ----- & ------ \\
\hline & 2000 & 205 & $+8.32(4)$ & 8.69 \\
\hline & 2005 & 232 & $+2.51(5)$ & 28.01 \\
\hline & 2010 & 309 & $+5.90(5)$ & 12.09 \\
\hline & 2016 & 373 & $+3.19(6)$ & 22.09 \\
\hline & 2005-1996 & ------ & $+5.05(9)$ & 14.09 \\
\hline & 2016-2005 & ------- & +4.04 (11) & 16.05 \\
\hline & 2016-2000 & ------- & +3.81 (16) & 18.53 \\
\hline & 2016-1996 & ------- & $+4.69(20)$ & 15.11 \\
\hline
\end{tabular}

*Insufficient directory data available for Smicksburg, Pennsylvania, which is the 11th largest settlement (Young Center for Anabaptist and Pietist Studies, 2020c).

**Total number of households for 2009 and 2014 come from end-of-year statistics found in The Diary. 